\title{
106. Effects of Temperature on Membrane Currents of the Frog Myocardium
}

\section{Enhancement of the Ca Inward Current at Lower Temperatures}

\author{
By Masayosi Goto, Masahiko SAIto,*) Yoshimi Iкемoto, \\ and Yasuo TsudA \\ Department of Physiology, School of Medicine, Kyushu University, Fukuoka \\ (Communicated by Kenji YamaokA, M. J. A., Sept. 13, 1976)
}

It has long been known that in myocardium a lowering of temperature produces a marked prolongation of the action potential (AP) and an augmentation of twitch contraction (cf. Blinks \& KochWeser, 1963), the augmentation being generally considered to be due to the long-lasting AP. Recently, however, several kinds of membrane currents $\left(\mathrm{I}_{\mathrm{Na}}, \mathrm{I}_{\mathrm{Nas}}, \mathrm{I}_{\mathrm{Ca}}, \mathrm{I}_{\mathrm{K} 1}\right.$ etc. $)$ have been recorded from myocardium (Rougier et al.,2) 1969; Reuter, ${ }^{3)}$ 1973; Trautwein,, ${ }^{4}$ 1973), and complicated processes of the membrane excitation-contraction (E-C) coupling have become much clearer (cf. Harris \& Opie, ${ }^{5)} 1971$; Coraboeuf, ${ }^{6)} 1973$; Langer, ${ }^{7)}$ 1973). The present study was undertaken to elucidate the fundamental effects of temperature on these membrane currents and on the E-C coupling processes.

The preparations used were thin muscle bandles (diameter 0.4$0.6 \mathrm{~mm}$ ) isolated from the right atrium of the bullfrog, Rana Catesbiana. The membrane potentials, currents and tensions were measured simultaneously by means of the conventional double-gap method described in a preceding report (Goto et al.,8) 1974), in which the muscle chamber consisted of five compartments. With this apparatus, gap action potentials of more than $100 \mathrm{mV}$ were commonly obtained and the short circuiting factor was greater than 0.8 . The solutions which flowed through each compartment were cooled or warmed at the entrance with the aid of a large water bath, the temperature of which was regulated to between $3^{\circ}$ and $37^{\circ} \mathrm{C}$. The actual temperature of the central test chamber was directly measured by a thermistor (Nihon Kohden, MGA 3-219). The compositions of normal Ringer solution and the test solutions used for the purpose of isolating specific membrane currents are shown in Table I. In this table, A is normal Ringer solution, B, Na-free (sucrose) Ringer solution, C, Ca-free EDTA Ringer solution, and D, Min Ringer solu-

\footnotetext{
*) Present Address: The 2nd Department of Internal Medicine, Faculty of Medicine, Tokushima University, Tokushima.
} 
Table I. Composition of solutions ( $\mathrm{mM} /$ liter)

\begin{tabular}{ccccccccc}
\hline Solution & \multirow{2}{*}{$\mathrm{NaCl}$} & Sucrose & $\mathrm{KCl}$ & $\begin{array}{c}\mathrm{CaCl}_{2} \\
2 \mathrm{H}_{2} \mathrm{O}\end{array}$ & $\begin{array}{c}\text { Tris- } \\
\mathrm{Cl}\end{array}$ & EDTA & $\begin{array}{c}\mathrm{MnCl}_{4 \mathrm{H}_{2} \mathrm{O}} \\
\text { Glucose }\end{array}$ \\
\hline A) & 109.84 & - & 2.56 & 1.80 & 10.0 & - & - & 5.80 \\
$\mathrm{~B})$ & - & 219.67 & 2.56 & 1.80 & 10.0 & - & - & 5.80 \\
C) & 109.84 & - & 2.56 & - & 10.0 & $5 \times 10^{-2}$ & - & 5.80 \\
D) & 109.84 & - & 2.56 & 1.80 & 10.0 & - & 3.00 & 5.80 \\
\hline
\end{tabular}
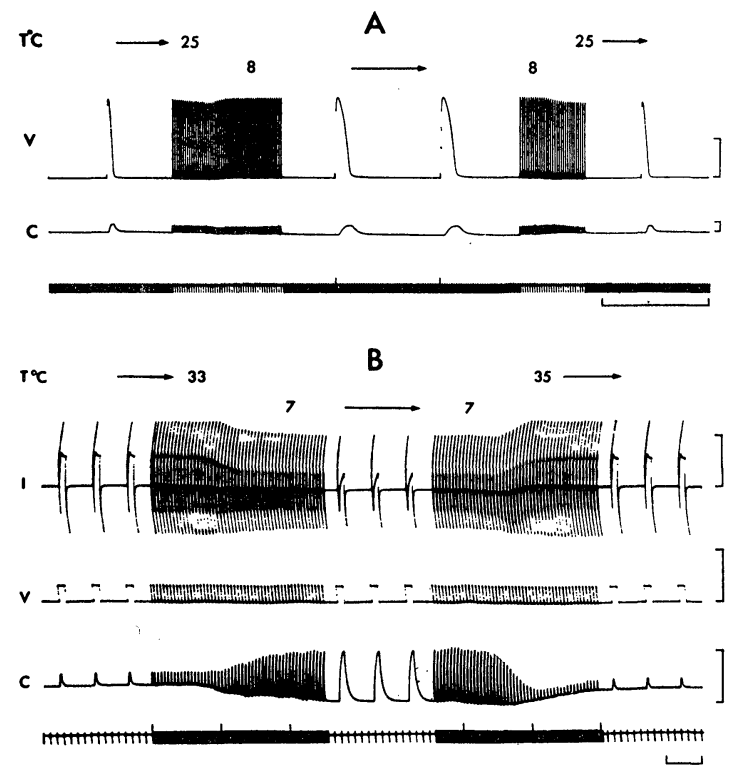

Fig. 1. A) Effects of temperature on the membrane potential (v) and tension (c) of bullfrog atrial muscle in normal Ringer solution. B) The same, showing the membrane current (i) and tension (c) under voltage (v) clamped conditions. The holding potential was $-72 \mathrm{mV}$ (resting potential level). The vertical bars are calibrations of $50 \mathrm{mV}$ and $0.75 \mathrm{~g}$ for $\mathrm{A}$, and $10 \mu \mathrm{A}, 200 \mathrm{mV}$ and $0.1 \mathrm{~g}$ for B. The horizontal bars, calibrations of time, $10 \mathrm{sec}$ and $10 \mathrm{~min}$ in $\mathrm{A}$, and $5 \mathrm{sec}$ and $1 \mathrm{~min}$ in $B$ for fast and slow records respectively.

tion. Solution B was used for the isolation of Ca inward current $\left(\mathrm{I}_{\mathrm{Ca}}\right)$, solution $\mathrm{C}$, containing freshly prepared TTX $\left(2 \times 10^{-6} \mathrm{~g} / \mathrm{ml}\right)$ for the isolation of slow $\mathrm{Na}$ inward current $\left(\mathrm{I}_{\text {Nas }}\right)$, and solution $\mathrm{D}$, for both fast $\mathrm{Na}$ inward current $\left(\mathrm{I}_{\mathrm{Naf}}\right)$ and delayed outward current $\left(I_{x}\right)$ since they did not overlap.

Fig. 1A shows the general effects of temperature on the electromechanical properties of the myocardium when it was cooled from $25^{\circ}$ to $8^{\circ} \mathrm{C}$. An increase in amplitude and a marked prolongation of the AP occurred being accompanied by a slight depolarization of the 
membrane, a decrease of basal tension and an increase of twitch contraction. Under voltage clamped conditions, also, a marked augmentation of contraction occurred despite a decrease in basal tension, even when constant depolarizing pulses from a constant holding potential level (resting potential) were applied (Fig. 1B). These simple findings indicate that the inotropic effect of low temperature is not merely due to a prolongation of the AP but also to some acceleration of $\mathrm{E}-\mathrm{C}$ coupling processes.

Basal membrane current level lowered with lowering of temperature, corresponding to the depolarization observed in the unclamped condition. Active inward currents were slowed and prolonged on the whole, and delayed outward current was inhibited, although they overlapped considerably in normal solution. However, when the component membrane currents were isolated in modified Ringer solutions (Table I) and the temperature was changed, it became clear that $I_{\mathrm{Ca}}$ markedly increased while $\mathrm{I}_{\mathrm{Naf}}$ diminished
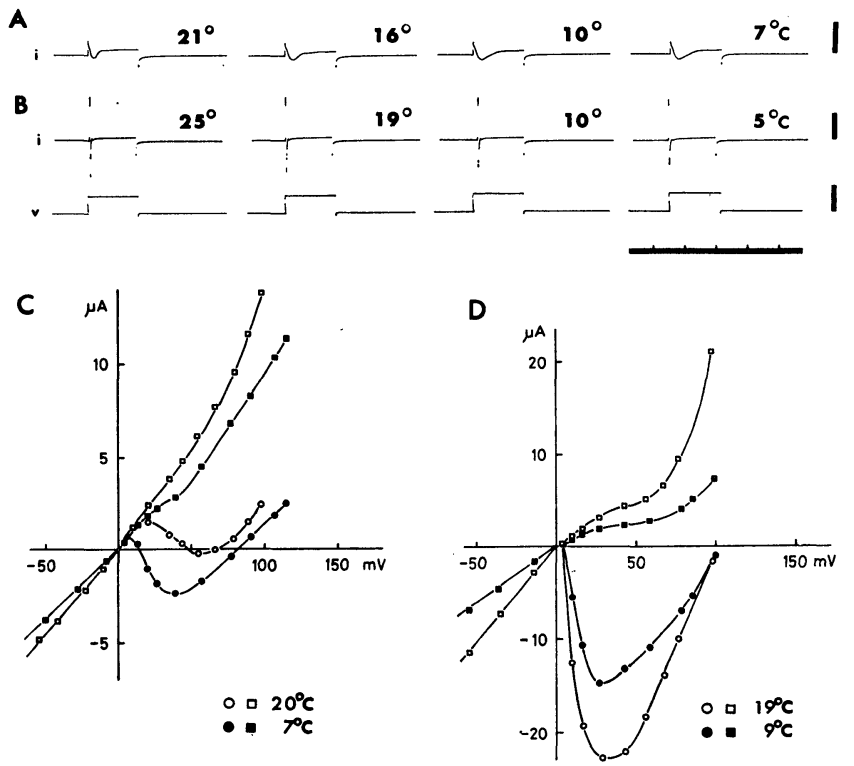

Fig. 2. Temperature and membrane currents of the bullfrog atrium. A) Effects of temperature on $\mathrm{I}_{\mathrm{Ca}}$ isolated in Na-free (sucrose) Ringer solution. B) The same, but showing membrane currents isolated in $\mathrm{Mn}$ Ringer solution. The vertical bars are calibrations of $10 \mu \mathrm{A}$ for $\mathrm{A}$, $20 \mu \mathrm{A}$ for $\mathrm{B}$, and $50 \mathrm{mV}$ for $\mathrm{A}$ and $\mathrm{B}$. The calibration of time, 1 sec. C) Voltage-current relationships in Na-free Ringer solution at high $(\square, \bigcirc)$ and low temperatures $(\square, \bullet)$. The square marks the level of the terminal current, and the circle, the peak of the dynamic current. D) Voltage-current relationships in Mn Ringer solution. $I_{N a f}$ and $I_{X}$ were inhibited at low temperature. Inhibition of $I_{1}$ is also apparent in $\mathrm{C}$ and $\mathrm{D}$. 
(Fig. 2A, B). Relationship between the amplitudes of depolarizing pulses and membrane currents also showed that this was valid for all voltage ranges where each current flowed (Fig. 2C, D). Leaky membrane current $\left(I_{1}\right)$ for hyperpolarizing pulses and delayed outward current $\left(I_{x}\right)$ for strong depolarizing pulses were both depressed at low temperature, indicating an increase in membrane resistance.

The finding of increase in $I_{\mathrm{Ca}}$ was rather unexpected, since in many excitable cells dynamic inward currents are known to be depressed at low temperature. The enhancement of $I_{\mathrm{Ca}}$ in the myocardium, however, could explain the appearance of a marked augmentation of twitch contraction under voltage clamp despite the lowering of basal tension (Fig. 1B). It may also account for the increase of AP amplitude accompanied by a depolarization of membrane at low temperature (Fig. 1A), which otherwise is difficult to explain.

The cause of an increase in $I_{\mathrm{Ca}}$ is unknown at present. In frog skeletal muscle, however, it is known that a higher amount of Ca is bound in the membrane at low temperatures than at high temperatures (Apter \& Koketsu, ${ }^{9)}$ 1960; Koketsu, ${ }^{10)}$ 1965), and that, in guinea-pig taenia-coli, cooling appears to increase the $\mathrm{Ca}$ at the outer layer of the membrane and to decrease it at the inner layer (Brading, Bülbring \& Tomita, ${ }^{11)}$ 1969). If these processes also occur in frog myocardium, an increase of $\mathrm{I}_{\mathrm{Ca}}$ would be expected because of an enhancement of inwardly directed driving force of Ca ions. Moreover, a decrease of $\mathrm{Ca}$ in the inner layer might explain a decrease of basal tension as well as of K-permeability (Frankenhaeuser \& Hodgkin, $\left.{ }^{12)} 1957\right)$ resulting in a reduction of membrane conductance, $I_{1}$ and $I_{x}$ at low temperatures.

\section{References}

1) Brinks, J. R., and Koch-Weser, J. (1963) : Pharmacol. Rev., 15, 531-599.

2) Rougier, O., Vassort, G., Garnier, D., Gargouil, Y. M., and Coraboeuf, E. (1969): Pflügers Arch., 308, 91-110.

3) Reuter, H. (1973) : Progress in Biophy. Mol. Biol., 26, 1-43.

4) Trautwein, W. (1973): Physiological Rev., 53, 793-835.

5) Harris, P., and Opie, L. H. (1971): Calcium and the Heart. Academic Press, London and New York.

6) Coraboeuf, E. (1973) : Circulation Research. Supl., 1, 59-61.

7) Langer, G. A. (1973) : Ann. Rev. Physiol., 35, 55-86.

8) Goto, M., Wada, Y., and Saito, M. (1974) : Jap. J. Physiol., 24, 359-375.

9) Apter, J. T., and Koketsu, K. (1960) : J. Cell. Comp. Physiol., 56, 123-127.

10) Koketsu, K. (1965) : Proc. Int. Physiol. Sci., 4, 521-541.

11) Brading, A., Bülbring, E., and Tomita, T. (1969) : J. Physiol., 200, 621-635.

12) Frankenhaeuser, B., and Hodgkin, A. L. (1957): J. Physiol., 137, 218-244. 